\title{
Factors Affecting Poverty Rates in West Java Province for the 2017- 2020 Period
}

\author{
Hartanto Halim \\ Borobudur University Jakarta, Indonesia \\ Corresponding author email: hartantohalim35@gmail.com
}

\author{
Musa Hubeis \\ Borobudur University Jakarta, Indonesia \\ Email: hubeis.musa@yahoo.com \\ Pudji Astuty \\ Borobudur University, Jakarta, Indonesia \\ Email: pudjiastuty1106@gmail.com
}

\begin{abstract}
This study aims to determine the factors that influence the poverty rate in the province of West Java for the period 2017-2020. In this study, the data used is secondary data with quantitative methods using panel data types where the number of samples is taken from 27 cities in the province of West Java. In this study, the results obtained are Partially the inflation variable has a positive and significant effect, Partially the income per capita variable positive and significant effect, Partially the variable of economic growth is positive and significant then Partially the income variable of People's Purchasing Power is positive and significant.
\end{abstract}

Keywords---economic growth, environmental conditions, income level, poverty rate, poverty reduction

\section{Introduction}

Poverty is a complex problem that is influenced by various interrelated factors, including income level, health, education, access to goods and services, location, geography, gender, and environmental conditions. Referring to the national strategy for poverty reduction, the definition of poverty is a condition in which a person or group of people, men, and women, have not fulfilled their basic rights to maintain and develop a life with dignity (Riani et. al., 2018). Basic rights that are generally recognized include the fulfillment of the needs for food, health, education, employment, housing, clean water, land, natural resources, and the environment, a sense of security from treatment or threats of violence, and the right to participate in social life. politics, both for women and men (Choi et al., 2020; Chu et al., 2020; Del Giudice et al., 2020; Fosu, 2017).

One of the factors that affect the level of poverty is inflation, which is the tendency to increase the price of goods and services in general, which takes place continuously. If the price of goods and services in the country increases, then inflation will increase (Klasen, 2008; Donaldson, 2008; Moore \& Donaldson, 2016; Ljupco \& Jasminka, 2017). The increase in the price of goods and services causes a decrease in the value of money. Thus, inflation can also be interpreted as a decrease in the value of money against the value of goods and services in general. Inflation plays an important role in determining economic conditions. Inflation directly or indirectly affects the economy, if people perceive high inflation it will affect the economy as a whole. "Inflation as a condition in which the general price level increases" (Samuelson, 2004). The purpose of this definition indicates a weakening of people's purchasing power followed by a decrease in the real (intrinsic) value of a country's currency. 


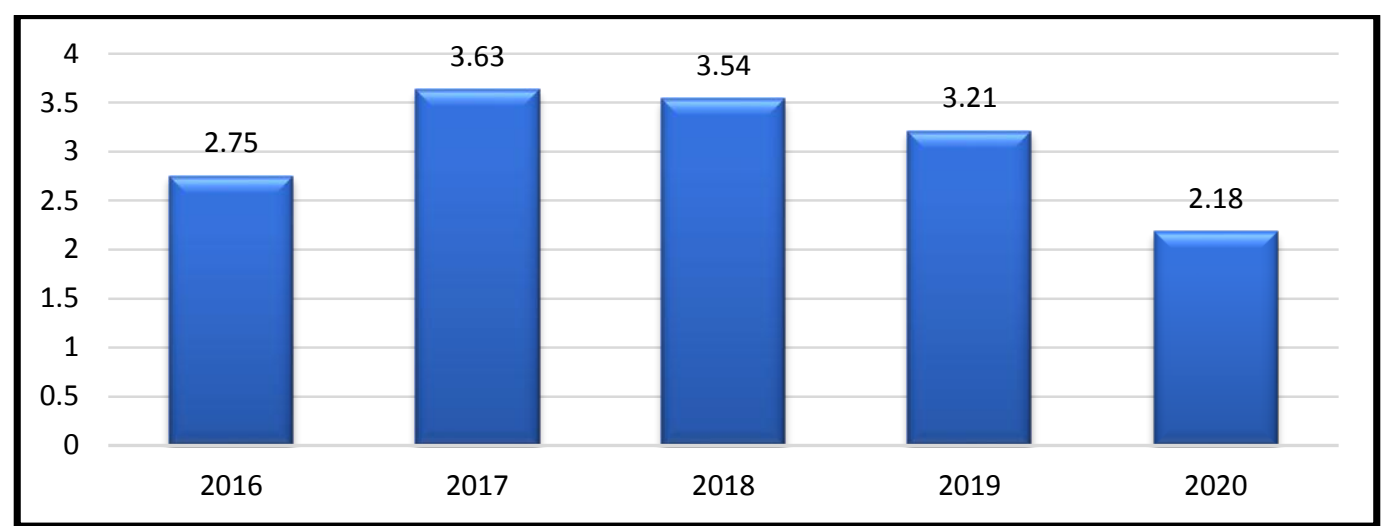

Figure 1. Cities combined annual inflation progress West Java Province, 2016 - 2020 (Percent)

(Source: BPS West Java Province, processed)

Based on Figure 1, in general, the combined inflation of 7 (seven) cities in West Java during 2020 was 2.18 percent. In 2019 (Gujarati, 2021). the combined inflation of 7 (seven) cities reached 3.21 percent. During the last five years, inflation in 2020 was the lowest annual inflation. The highest inflation occurred in 2017 at 3.63 percent. West Java inflation in 2020 is still within the target range of 3 percent \pm 1 percent, in line with the still limited economic improvement.

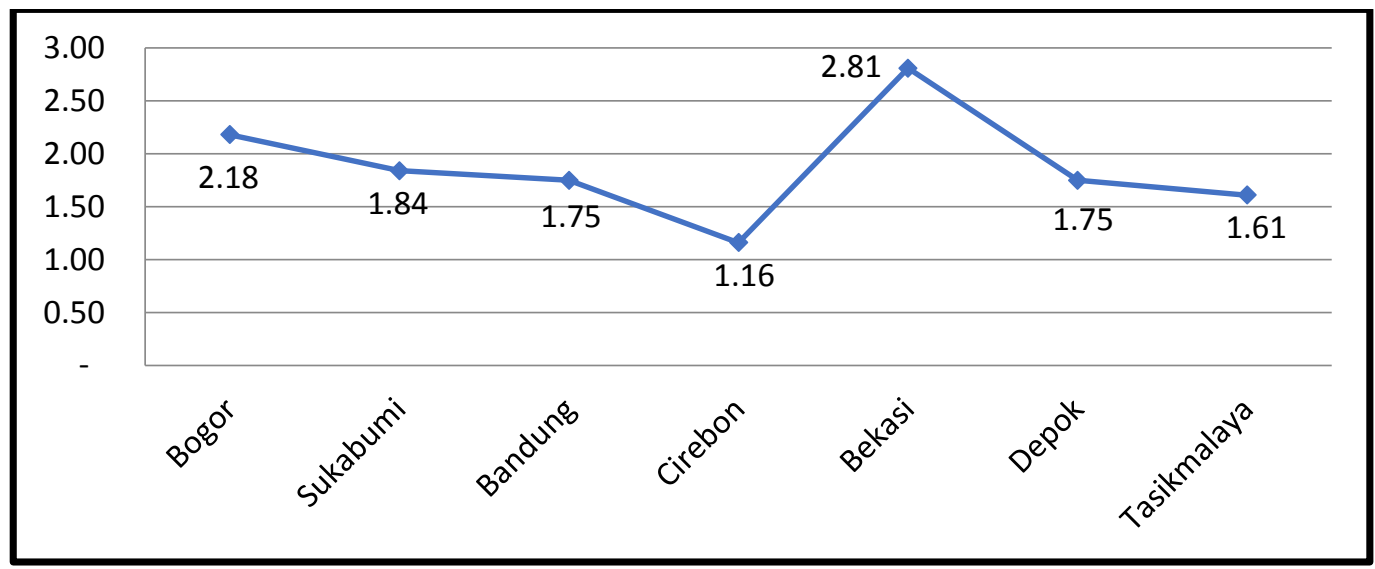

Figure 2. Inflation of seven cities in West Java Province 2020 (Percent)

(Source: BPS West Java Province 2020, processed)

Based on figure 2 above, the combined inflation of 7 cities in West Java in 2020 reached 2.18 percent (yoy). Bekasi City is the area that has the highest inflation rate in West Java in 2020, which is 2.81 percent. Followed by the city of Bogor by 2.18 percent. In these two regions, inflation achievement is higher than the average for West Java, while the other five cities are lower than West Java. Cirebon City is the area with the lowest inflation in West Java at 1.16 percent. Sukabumi City, Bandung City, and Depok City along with Tasikmalaya City are the areas where inflation achievement is below 2 percent. The two cities with the highest inflation in West Java have similar characteristics, namely acting as a consumer area and not a producer area. This causes the two regions to have a high dependence on areas that supply consumption materials (Collier \& Dollar, 2002; Zager et al., 2011; Pegg, 2006; Barrett et al., 2005).

Thus, inflationary pressures in these two regions are highly dependent on distribution patterns (Adisasmita, 2013). On the other hand, the two cities are also very close to the capital city of Jakarta so the inflation pattern tends to be more influenced by Jakarta's inflation movements. West Java's per capita income, which is seen in real terms, based on 2010 constant prices (ADHK) in 2020 is only Rp. 29.14 million rupiahs. This value is even lower than the GRDP per capita of ADHK in 2018 which was Rp. 29.16 million rupiahs. The rate of GRDP per capita in 2020 decreased by 3.65 percent when compared to 2019 , and when compared to 2018 it decreased by 0.06 percent. This indicates that the economy is in a slump due to the COVID-19 pandemic (Wijantari \& Bendesa, 2016; Wibowo \& Khoirudin, 2019; Winarno, 2017; Wirasasmita, 2012). 


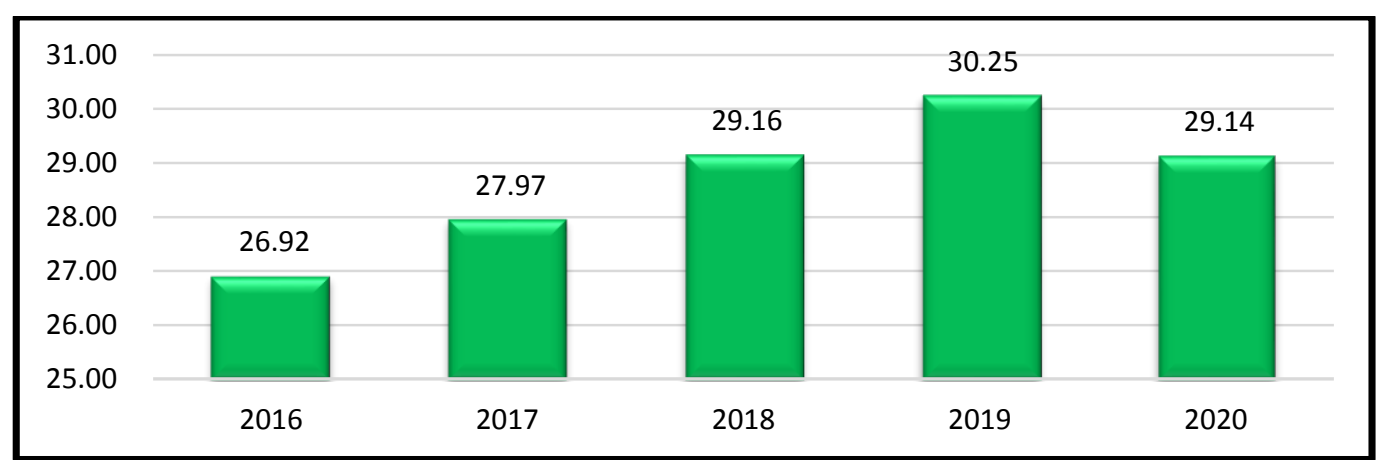

Figure 3. GRDP per capita at constant prices (ADHK) 2010. West Java Province 2016 - 2020 (Million Rupiah)

(Source: BPS West Java Province, processed)

From the Figure 3. West Java's per capita income which is seen in real terms, namely based on constant prices (ADHK) 2010 in 2020 is only Rp. 29.14 million rupiah. This value is even lower than the GRDP per capita of ADHK in 2018 which was Rp. 29.16 million rupiah (WULANDARI et al., 2019). The rate of GRDP per capita in 2020 decreased by 3.65 percent when compared to 2019 , and when compared to 2018 it decreased by 0.06 percent. This indicates that the economy is in a slump due to the COVID-19 pandemic.

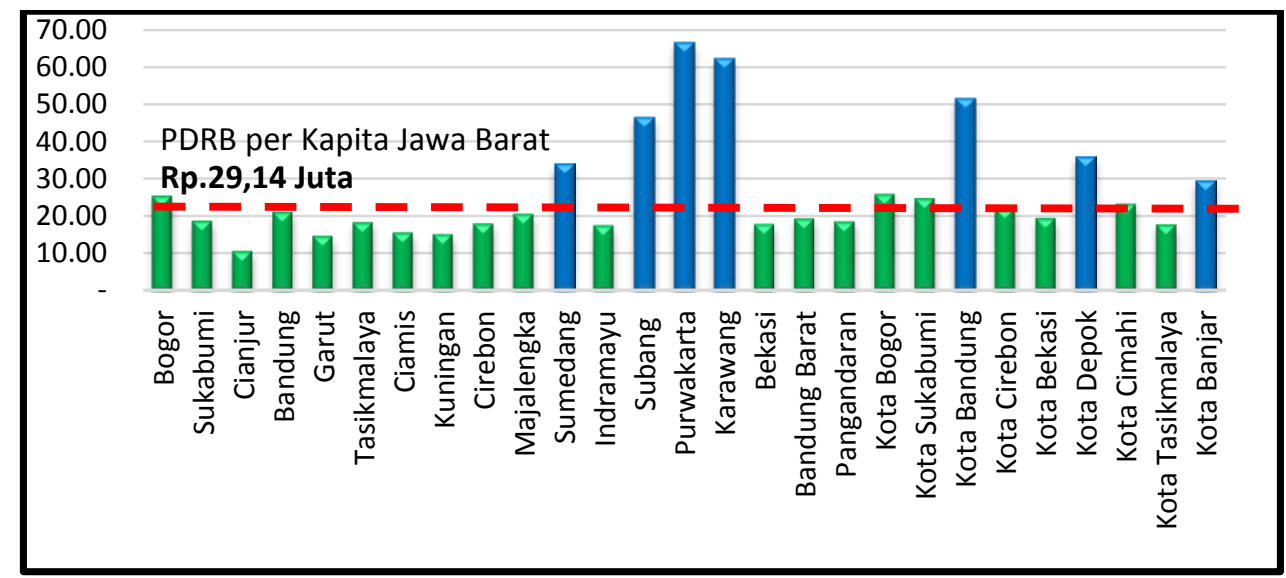

Figure 4. GRDP per capita at constant prices (ADHK) 2010 by Regency/City of West Java Province in 2020 (Source: BPS West Java Province 2020, processed)

Based on Figure 4, there are 7 (seven) regencies/cities in West Java province with a per capita income figure that is above the provincial per capita income in 2020 of Rp. 29.41 million, including Sumedang district of Rp. 34.07 million (Wibowo \& Khoirudin, 2019). Subang district of Rp. 46.64 million, Purwakarta district of Rp. 66.59 million, Karawang district of Rp. 62.37 million, Bandung city of Rp. 51.64 million, Depok city of Rp. 36.01 million and Banjar city of Rp. 29.49 million. Meanwhile, 20 (twenty) other regencies/cities are below the per capita income of West Java province.

West Java's economic growth rate in 2020 contracted by 2.44 percent compared to 2019 which was 5.07 percent. The correction in West Java's economic growth was influenced by the COVID-19 pandemic which had an impact on the economy (Siahaan, 2005; Stavytskyy et al., 2019; Sukirno, 2006; Todaro \& Smith, 2021). This condition causes an economic slowdown. In terms of production, the largest slowdown was shown in the company's service business field, which contracted by 18.38 percent. From the expenditure side, the decline occurred in all components. Components that contributed to a significant negative share were changes in inventory of -62.35 percent, followed by the component of gross fixed capital formation of -8.34 , exports of goods and services by -6.55 percent, and components of non-profit private consumption and household consumption expenditures. respectively -3.78 percent and -2.89 percent. The components of imports of goods and services that act as a deduction for economic growth decreased by -17.07 percent.

Poverty in the province of West Java is a problem that has yet to be resolved. Poverty can have a fairly serious effect on human development because the problem of poverty is a complex problem that starts from the purchasing 
power of people who are unable to meet their basic needs so that other needs such as education and health can be neglected (Gil-Alana \& Yaya, 2021; Haji-Othman \& Yahaya, 2015; Niu et al., 2016). The problem of poverty in the West Java region is complex and multidimensional. Therefore, poverty alleviation efforts must be carried out properly, cover various aspects of people's lives, and be implemented in an integrated manner. The poverty rate in the province of West Java can be seen in Figure:



Figure 5. Number and percentage of poor population in West Java Province 2016 - 2020.

(Source: BPS West Java Province, processed)

Based on figure 5, the number and percentage of poor people in West Java province continued to decline in the period 2016 to 2019 (Mankiw, 2017). In 2019 it reached its lowest point of 3.39 million people or 6.82 percent of the entire population of West Java, down compared to 2016 when the poor reached 4.22 million people or 8.77 percent. However, in 2020, during the COVID-19 pandemic, the number of poor people increased by 3.92 million or 7.88 percent.

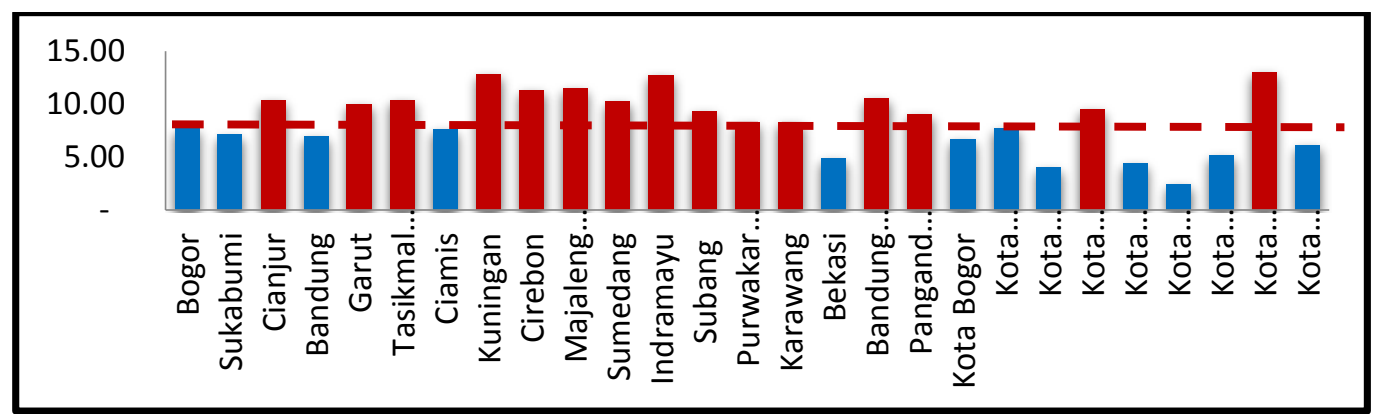

Figure 6. The highest poverty rate in West Java

(Source: BPS West Java Province 2020, processed)

Based on the figure: the highest poverty rate in West Java is in the city of Tasikmalaya, which is recorded at 12.97 percent, while the district/city with the lowest poverty rate is in the city of Depok, which is recorded at 2.45 percent. Of the 27 districts/cities in West Java, as many as 15 districts/cities have a poverty rate higher than the poverty rate of West Java. While the remaining 12 have a poverty rate lower than the poverty rate of West Java (Purnomo et al., 2020; Iskandar, 2013; Rini \& Sugiharti, 2016; Ravallion, 2002). The majority of districts/cities with high poverty rates are in the southern region of West Java. This shows that there is inequality or uneven economic development in West Java. Most of the people living in areas with high poverty rates work in the agricultural sector. On the other hand, people living in areas with low poverty rates tend to have more diverse professions, such as in the manufacturing sector or the service sector (Seshaiah \& Tripathy, 2018; Sedyaningrum \& Nuzula, 2016; Setyadi \& Indriyani, 2021).

\section{Methods}

\section{Types of research}

Based on the analytical approach, this study uses a quantitative method with an associative approach to causal techniques (Wirasasmita, 2012). The data used is a secondary data type balance panel. The data in this study are 
secondary data whose collection is in the form of 27 (twenty-seven) districts/cities and data for 3 (three) years, namely from 2017 to 2020 . The data analysis in this study uses inferential statistical analysis, namely to obtain conclusions from research results. Data collection techniques are:

- Questionnaire by distributing several questions that must be filled in format

- In-depth interviews to explore answers that focus on problems

- Field survey to find phenomena that occur in the field

- Literature study to complete and support theories related to research

\section{Result}

\section{Poverty level}

The poverty rate of West Java province in 27 (twenty-seven) regencies/cities during the study period 4 (four years) 2017 - 2020, with 108 (one hundred and eight) research samples having an average poverty rate of 8.46 percent. (Hidayati \& Maskuri, 2020). The highest poverty rate was recorded in the city of Tasikmalaya in 2017 at 15.60 percent, while the lowest poverty rate was recorded in the city of Depok in 2019 at 2.07 percent, with a standard deviation of 2.91 percent.



Figure 7. The poverty rate of West Java Province

\section{Normality test results}

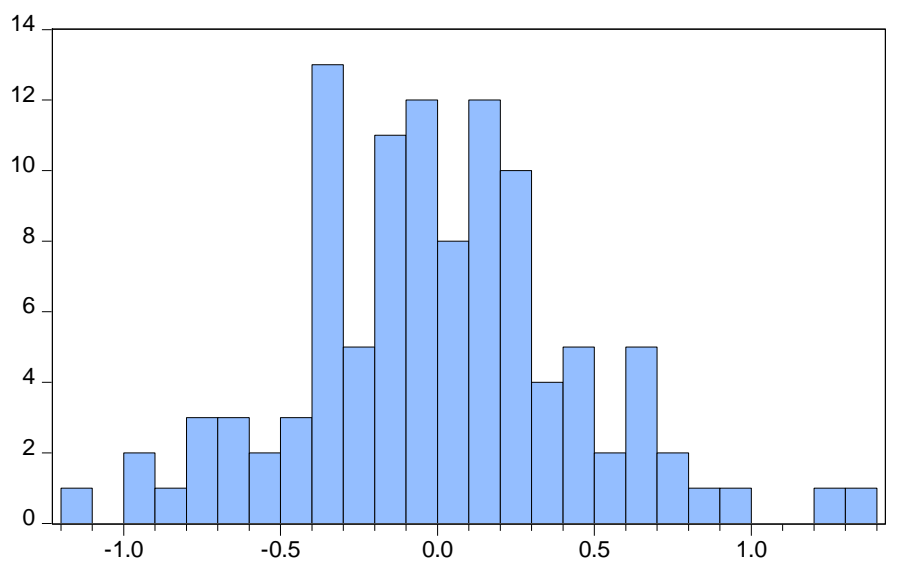

\begin{tabular}{lc} 
Series: Standardized Residuals \\
Sample 2017 2020 \\
Observations & 108 \\
& \\
Mean & 0.000000 \\
Median & -0.008821 \\
Maximum & 1.334442 \\
Minimum & -1.172149 \\
Std. Dev. & 0.446125 \\
Skewness & 0.178340 \\
Kurtosis & 3.459495 \\
& \\
Jarque-Bera & 1.522604 \\
Probability & 0.467058 \\
\hline
\end{tabular}

Figure 8 . The results of the normality test

In the Figure 8 above, we can conclude that the results of the Normality test show that the data is normally distributed, namely the J-B value of $1.522>0.05$, which means that the data is normally distributed. 


\section{Panel data regression analysis results}

After doing the three tests, the Cammon Effect model, Fix Effect Model, Random Effect Model, and going through the stages of Chow and Hausman, the best result was selected in the Fix effect model.

Table 1

The best result was selected in the fix effect model

\begin{tabular}{lllll}
\hline Variable & Coefficient & Std. Error & t-Statistic & Prob. \\
\hline Inflasi & 0.169732 & 0.101530 & 1.671747 & 0.0986 \\
Pen_kapita & $-1.21 \mathrm{E}-09$ & $7.86 \mathrm{E}-09$ & -0.153370 & 0.8785 \\
Per_ekon & -0.065344 & 0.024105 & -2.710813 & 0.0083 \\
Daya_beli & $-1.79 \mathrm{E}-06$ & $2.10 \mathrm{E}-07$ & -8.490315 & 0.0000 \\
C & 27.18497 & 2.390901 & 11.37018 & 0.0000 \\
\hline \multicolumn{5}{c}{} \\
\hline Cross-section fixed (dummy variables) \\
\hline R-squared & 0.876541 & Mean dependent var & 8.457407 \\
Adjusted R-squared & 0.867401 & S.D. dependent var & 2.912717 \\
S.E. of regression & 0.525900 & Akaike info criterion & 1.788338 \\
Sum squared resid & 21.29598 & Schwarz criterion & 2.558209 \\
Log likelihood & -65.57026 & Hannan-Quinn criter. & 2.100493 \\
F-statistic & 106.8421 & Durbin-Watson stat & 2.19004 \\
Prob(F-statistic) & 0.000000 & & \\
\hline
\end{tabular}

Panel data regression equation

Poverty $=27.184+0.169732 \_$inf -1.21 E_Pen_kap -0.065344 per_eko -1.79 E_Dayabeli $+\varepsilon 1$

Partial test ( $t$-test)

- Partially the inflation variable has a positive and significant effect with a prob value of $0.0986>0.05$

- Partially the income per capita variable has a positive and significant effect with a prob value of $0.0083>0.05$

- Partially the variable of economic growth is positive and significant with a prob value of $0.000>0.05$

- Partially, the income variable of Community Purchasing Power is positive and significant with a prob value of $0.000>0.05$

\section{F-Simultaneous test}

From the regression table, the F-Statistic value of $0.0000<0.05$ means that simultaneously the variables of inflation, per capita income, economic growth, people's purchasing power have a positive and significant impact on poverty (Monadjemi \& Lodewijks, 2021; Pamungkas, 2018; Nugroho \& Dahuri, 2012; Deori, 2015).

\section{Conclusion}

- Inflation has no effect on the level of poverty that occurred in the province of West Java for the period 20172020

- Per capita income has no effect on the poverty rate that occurred in the province of West Java for the 20172020 period

- Economic growth has an influence on the level of poverty that occurs in the province of West Java for the period 2017-2020

- People's purchasing power has an influence on the level of poverty that occurred in the province of West Java for the period 2017-2020. 


\section{Suggestion}

- Although inflation has no effect on the poverty level in the province of West Java, the movement of inflation must still be monitored by the government.

- Economic growth needs to be considered every year so that it remains stable and tends and always increases.

- Increasing people's purchasing power in order to help economic growth and reduce poverty.

\section{References}

Adisasmita, R. (2013). Theories of economic development. Yogyakarta, Graha Ilmu.

Barrett, C. B., Lee, D. R., \& McPeak, J. G. (2005). Institutional arrangements for rural poverty reduction and resource conservation. World Development, 33(2), 193-197. https://doi.org/10.1016/j.worlddev.2004.07.008

Choi, C. Y., Choi, H., \& Chudik, A. (2020). Regional inequality in the US: Evidence from city-level purchasing power. Journal of Regional Science, 60(4), 738-774.

Chu, M. Y., Law, T. H., Hamid, H., Law, S. H., \& Lee, J. C. (2020). Examining the effects of urbanization and purchasing power on the relationship between motorcycle ownership and economic development: A panel data. International Journal of Transportation Science and Technology. https://doi.org/10.1016/j.ijtst.2020.12.004

Collier, P., \& Dollar, D. (2002). Aid allocation and poverty reduction. European economic review, 46(8), 1475-1500. https://doi.org/10.1016/S0014-2921(01)00187-8

Del Giudice, V., De Paola, P., \& Del Giudice, F. P. (2020). COVID-19 infects real estate markets: Short and mid-run effects on housing prices in Campania region (Italy). Social sciences, 9(7), 114.

Deori, B. (2015). An analysis of rural poverty alleviation programs and challenge in Assam: a micro level study of margherita block of tinsukia district. International Research Journal of Management, IT and Social Sciences, 2(7), 10-14. Retrieved from https://sloap.org/journals/index.php/irjmis/article/view/313

Donaldson, J. A. (2008). Growth is good for whom, when, how? Economic growth and poverty reduction in exceptional cases. World development, 36(11), 2127-2143. https://doi.org/10.1016/j.worlddev.2007.10.020

Fosu, A. K. (2017). Growth, inequality, and poverty reduction in developing countries: Recent global evidence. Research in Economics, 71(2), 306-336. https://doi.org/10.1016/j.rie.2016.05.005

Ghozali, I. (2014). Econometrics Theory, Concepts and Applications with IBM SPSS22. Semarang: Diponegoro University.

Gil-Alana, L. A., \& Yaya, O. S. (2021). Testing fractional unit roots with non-linear smooth break approximations using Fourier functions. Journal of Applied Statistics, 48(13-15), 2542-2559.

Gujarati, D. N. (2021). Essentials of econometrics. SAGE Publications.

Haji-Othman, Y., \& Yahaya, S. (2015). Purchasing power parity: evidence from selected high and low inflation countries. International Business Research, 8(1), 50.

Hidayati, N., \& Maskuri, M. A. (2020). Inflasi, Tingkat Pengangguran Dan Daya Beli Masyarakat Di Kabupaten Bogor. Jurnal Manajemen Kewirausahaan, 17(2), 137-142.

Iskandar, P. (2013). Economics pengantar mikro dan Makro. Jakarta: Mitra Wacana Media.

Jeke, L., \& Wanjuu, L. Z. (2021). The economic impact of unemployment and inflation on output growth in South Africa. Journal of Economics and International Finance, 13(3), 117-126.

Klasen, S. (2008). Economic growth and poverty reduction: measurement issues using income and non-income indicators. World development, 36(3), 420-445. https://doi.org/10.1016/j.worlddev.2007.03.008

Ljupco, N., \& Jasminka, N. (2017). Unemployment an unauthorized unique road about apathy and poverty the Macedonian man without knowledge and skills. International Research Journal of Management, IT and Social Sciences, 4(4), 44-57. Retrieved from https://sloap.org/journals/index.php/irjmis/article/view/473

Mankiw, N. G. (2017). Principles of macroeconomics. Boston: Cengage Learning.

Mansur, A. (2019). Sharia banking dynamics and the macroeconomic responses: Evidence from Indonesia.

Monadjemi, M., \& Lodewijks, J. (2021). International Evidence on Purchasing Power Parity: A Study of High and Low Inflation Countries. Journal of Economics and Management Sciences, 4(3), p1-p1.

Moore, J. D., \& Donaldson, J. A. (2016). Human-scale economics: economic growth and poverty reduction in Northeastern Thailand. World Development, 85, 1-15. https://doi.org/10.1016/j.worlddev.2016.04.004

Niu, H., Chu, X., \& Ma, Y. (2016). Study on the Fluctuation of Purchasing Power Parity. Open Journal of Business and Management, 4(01), 67.

Nugroho, I., \& Dahuri, R. (2012). Regional Development perspectives on Economic. Social and Environmental. Jakarta: LP3ES. 
Pamungkas, P. A. (2018). The Impact Of Unemployment Rate, Labor Force, Capital, Inflation Rate, And Government Expenditure On Economic Growth In Indonesia. American Journal of Engineering Research, 7(3), 109-119.

Pegg, S. (2006). Mining and poverty reduction: Transforming rhetoric into reality. Journal of cleaner production, 14(3-4), 376-387. https://doi.org/10.1016/j.jclepro.2004.06.006

Purnomo, S. D., Istiqomah, I., \& Suharno, S. (2020). The Effect Ethnic on Poverty in DIY Province. JEJAK: Jurnal Ekonomi dan Kebijakan, 13(1), 135-148.

Ravallion, M. (2002). On the urbanization of poverty. Journal of Development Economics, 68(2), 435-442. https://doi.org/10.1016/S0304-3878(02)00021-4

Riani, D. D., Octavianus, R. J. N., \& Hutapea, T. M. H. (2018). Analysis Of Effect Of Exchange Rate, Inflation, And Power Purchase On Distribution Of Credit In Common Conventional Banks. Jurnal Aplikasi Manajemen, 16(2), 363-369.

Rini, A. S., \& Sugiharti, L. (2016). Faktor-faktor penentu kemiskinan di Indonesia: analisis rumah tangga. JIET (Jurnal Ilmu Ekonomi Terapan), 1(2).

Samuelson, L. (2004). Modeling knowledge in economic analysis. Journal of Economic Literature, 42(2), 367-403.

Sedyaningrum, M., \& Nuzula, N. F. (2016). Pengaruh Jumlah Nilai Ekspor, Impor Dan Pertumbuhan Ekonomi Terhadap Nilai Tukar Dan Daya Beli Masyarakat Di Indonesia Studi Pada Bank Indonesia Periode Tahun 2006: iv-2015: iii. Jurnal Administrasi Bisnis, 34(1), 114-121.

Sedyaningrum, M., \& Suhadak, N. N. (2016). The influence of total exports, imports and economic growth on exchange rates and the purchasing power of people in Indonesia. Journal of Business Administration (JBA), 34(1), 115-121.

Seshaiah, S. V., \& Tripathy, T. (2018). GDP purchasing power parity per capita and its determinants: A panel data analysis for BRICS. Theoretical Economics Letters, 8(3), 575-591.

Setyadi, S., \& Indriyani, L. (2021). Dampak Pandemi COVID-19 Terhadap Peningkatan Resiko Kemiskinan Di Indonesia. PARETO: Jurnal Ekonomi Dan Kebijakan Publik, 4(1), 53-66.

Siahaan, M. P. (2005). Pajak daerah dan retribusi daerah.

Stavytskyy, A., Kharlamova, G., \& Stoica, E. A. (2019). The analysis of the digital economy and society index in the EU. TalTech Journal of European Studies, 9(3), 245-261.

Sukirno, S. (2006). Ekonomi pembangunan: proses, masalah dan dasar kebijakan.

Todaro, M. P., \& Smith, S. C. (2021). Economic development.

Wibowo, A. R., \& Khoirudin, R. (2019). Analysis of Determinants of Poor Population in Central Java 20082017. Ekuilibrium: Jurnal Ilmiah Bidang Ilmu Ekonomi, 14(1), 1-15.

Wijantari, N. M. W., \& Bendesa, I. K. G. (2016). Kemiskinan Di Provinsi Bali (Studi Komparatif Kabupaten/Kota Di Provinsi Bali). Jurnal Buletin Studi Ekonomi, 2l(1), 13-25.

Winarno, W. W. (2017). Analisis ekonometrika dan statistika dengan eviews.

Wirasasmita, Y. (2012). Ilmu Ekonomi Makro Advance. Buku Ajar, Jakarta: FE Unbor.

Wirasasmita, Y. (2012). Metodologi Penelitian Ekonomi dan Bisnis Advance Buku Ajar. Jakarta: FE Unbor.

WULANDARI, D., UTOMO, S. H., NARMADITYA, B. S., \& KAMALUDIN, M. (2019). Nexus between inflation and unemployment: Evidence from Indonesia. The Journal of Asian Finance, Economics, and Business, 6(2), 269-275.

Zager, S., Mendu, M. L., Chang, D., Bazick, H. S., Braun, A. B., Gibbons, F. K., \& Christopher, K. B. (2011). Neighborhood poverty rate and mortality in patients receiving critical care in the academic medical center setting. Chest, 139(6), 1368-1379. https://doi.org/10.1378/chest.10-2594 